\title{
Land tenure in tea farming and exploring factors influencing a rural household's decision to exit or enter farming
}

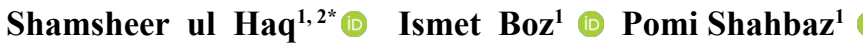 \\ ${ }^{1}$ Department of Agricultural Economics, Ondokuz Mayıs University, 55139, Samsun, Turkey. E-mail: shamsheer213@hotmail.com. \\ "Corresponding author. \\ ${ }^{2}$ Department of Economics and Business Administration, Division of Arts and Social Sciences, University of Education, Lahore, Punjab, \\ Pakistan.
}

ABSTRACT: Self-operated land and operated by tenure may affect the sustainability of farming in a region. This study planned to analyze how rural households switch away from tea farming even they have parental land, and how landless access the land for tea farming. For this a total of 138 tea growers were interviewed including 27 farmers who had just ownership of land and had left the tea farming. Logistic regression was applied to assess the determinants of rural household's decision to exit and enter the land market. Farmers were compared over their farm management practices and personal characteristics. The owned farmers were good in management and adoption of good practice in tea farming than those who accessed land as a shareholder and not had their own land. Rural households head as getting older, having high education and also having an off-farm occupation, having more university graduated family members, and family members having off-farm occupations are more likely to exit from farming and supply their land to rental markets. On the other side, an older and highly educated head of landless family is less likely to become a shareholder. Here also off-farm occupation has a negative and insignificant effect on the probability of landless household working as a shareholder. If the head of the landless family has a wish to become a successful farmer, then he is more likely to work as an owner. It implies that a person is less likely to work as a shareholder and more likely to get land with ownership rights not only land-using rights.

Key words: land tenure, owner and shareholder, tea farming, land rental market.

Um exame da posse da terra na agricultura de chá e a exploração de fatores que influenciam a decisão de uma família rural de sair ou entrar na agricultura

RESUMO: Propriedades auto-operados e operados pela posse podem afetar a sustentabilidade da agricultura em uma região. Este estudo planejou analisar como as famílias rurais se afastam da produção de chá, mesmo as que possuam terras parentais, e como os sem-terra acessam a terra para a produção de chá. Nesse total, 138 produtores de chá foram entrevistados, incluindo 27 agricultores que possuíam apenas a propriedade da terra e deixaram a lavoura. A regressão logística foi aplicada para avaliar os determinantes da decisão da família rural de sair e entrar no mercado de terras. Os agricultores foram comparados com suas práticas de gerenciamento agrícola e características pessoais. Os agricultores proprietários foram considerados bons em gestão e adoção de boas práticas na agricultura de chá do que aqueles que acessaram a terra como acionista e não possuíam terras próprias. Os agregados familiares rurais envelhecem, têm ensino superior e também uma ocupação fora da fazenda, tendo mais membros da família graduados na universidade e com ocupações fora da fazenda têm mais probabilidade de sair da agricultura e fornecer suas terras para os mercados de arrendamento. Por outro lado, um chefe de família sem terra, mais velho e altamente educado, tem menos chances de se tornar um acionista. Aqui também a ocupação fora da fazenda tem um efeito negativo e insignificante na probabilidade de familias sem terra trabalharem como acionistas. Se o chefe da familia sem terra deseja se tornar um agricultor bem-sucedido, é mais provável que ele trabalhe como proprietário. Isso implica que é menos provável que uma pessoa trabalhe como acionista e obtenha terras com direitos de propriedade e não apenas direitos de uso da terra.

Palavras-chave: posse da terra, proprietário e acionista, tea farming.

\section{INTRODUCTION}

Land tenure is a legal and customarily defined relationship among households, individuals or groups, with respect to land. It creates opportunities for landless households to access land for farming purpose via defining the rights of use. It is a way in which, the land is accessed, managed, and it is defined that who can control and use the land resources such as water, trees, etc. (BUGRI, 2008; USAID, 2013; FAO, 2017). Therefore, the land tenure is an emerging issue in rural areas for sustainable farming. Many structural changes in farming have altered the working opportunities for the rural labor force. 
Because obtaining land is an important factor for farming and land tenure system creates enhanced opportunities for the landless peoples to access land.

Land, as the basic and most important factor for farming requires a well-functioning land market just like other markets. Therefore, a costeffective and flexible mechanism to make productive use of land can transform the rural economy. Thus, it can also boost the welfare of rural people (De JANVRY et al., 2001). The literature regarding land tenure forms revealed that households are likely to access land as landlords, owners, tenants, and owners-cum-tenants (BASHIR et al., 2012; UL-HAQ et al. 2016; SHAHBAZ et al., 2017).

As an owner, the shareholders and renters are not similar in personal characteristics; their modes of operation can also affect their farming practices. Therefore, different objectives motivate landowners and tenants, which may have an impact on the adoption of best management practices at farming (COX, 2010). Globally, the land tenure and adoption of best management practices have been explained in detail and the factors in favor and against the land tenure farming for the adoption of best management practices have been explored. All farmers participate in these informal or formal land rental markets, which have a vital role in improving agricultural productivity and income of rural residents (DEININGER \& FEDER, 2001; DEININGER, 2003; DEININGER \& JIN, 2005). Many studies have explored the importance of land tenure security or clear land use rights in enhancing capital investment in agriculture and soil conservation. In addition, allocative efficiency, adoption of best management practices; food security and its impact on environmental sustainability (MAXWELL \& WIEBE, 1999; KATZ, 2000; BRASSELLE et al. 2002; GEBREMEDHIN \& SWINTON, 2003) have also been investigated. The cash and share renter are less likely to adopt best management practices as compared to landowners. It has been reported that insecure land tenure is a huge obstacle for long-term soil conservation (SOULE et al. 2000; FRASER, 2004; AFT, 2013). PRANEETVATAKUL et al. (2001) also reported that insecure land tenure may reduce the incentives to improve land productivity.

The different forms of land tenure exist in Turkey, wherein self-owned land (farmers who have rights to manage their land by themselves) 136.35 million decares, land of farmers who possess land but do not have ownership rights -3.93 million decares, rental based land - 3.08 million decares, and share-based land -2.56 million decares are under cultivation. Beside this, 38.44 million decares are also operated in other forms of land tenureship. Total 3.022 million households are operating 184.35 million decares of land, out of which 0.927 million households are operating 5.64 million decares as renters or as shareholders. In the Rize province, almost 50,000 households are holding land in different categories, which is equal to 0.58 million decares. Moreover, 1686 households possess 16,952 decares on share basis (TUIK, 2017).

Development of land tenure market plays an important role in improving agricultural productivity and income of rural families. Similarly, in the tea-producing area, rural households participating in the informal land accessing system (shareholding) have a common objective to improve their welfare status by enhancing tea production and income. The farmers who do not possess parental land are motivated to participate in tea-farming by acquiring agricultural land for tea farming. For the majority of such farmers, the motivating factors are to produce an increased tea-production for which different types of informally arranged land rental contracts are used (TEKLU \& LEMI, 2004). The major types of contracts are the self-owned operated contracts and shareholding arrangements in tea farming in the Rize province. Most of the shareholding arrangements are oral contracts between the real owners of the land and the shareholders (landless households). The aim of this study was to analyze the informal land market, particularly the key factors that influence the decision of the farmers to leave tea farming and give land to shareholders. Furthermore, this study explains determinants influencing a landless person's decision to become a shareholder farmer by accessing land on a share basis.

Decision making is a process of selecting a course of action from a number of alternatives to accomplish desired goals/objectives. Different scientists consider decision making a multi-step process ranging from five to eight steps. JOHNSON et al. (1961) defines decision making as a six step process including problem definition, observation, analysis, decision, action and responsibility bearing. Conversely, SIMON (1965) considers decision making as a three step process (intelligence, design, and choice). According to standard farm management theory, these decision making process must obey these steps in a linear way in each and every decision but sometimes decision makers do not follow these steps linearly in reality.

Therefore, this study has two important objectives: the first objective is to explain the types 
of farmers, their socio-economic characteristics, and their tea management practices. The second objective of the study is to describe the econometric model to assess the hidden determinants which may influence landholders' decisions to make land available in the market and also to assess decisions of landless farmers to acquire land on a share basis.

\section{Theoretical background}

Theory either forecast or elucidates an event. Therefore, theory established by human being helps to understand our complex surrounding environment (TURNER et al., 2018). Thus, a theory also provides important information about certain actions performed or taken by human beings such as why farmers enter or exit in farming. In a pure competitive market, the decision to exit/shut down or enter in a market is made by comparing output price with short run average variable cost or average total cost under certain assumptions such as perfect information and no entry and exit barriers. Even though, pure market competition is the most desirable market condition for the society but agriculture markets do not fulfill the perfect market conditions mainly due to the nature of the capital used, time lags that exist between cultivation and harvesting, imperfect market information and fluctuating future crop prices. Relaxing the pure competitive market condition of perfect information, the agriculture markets exhibits seasonal price variations because of market clearing conditions and government price mechanisms for different agricultural crops. Therefore, agriculture output decisions are based on both current as well as future expected crop prices (FOLTZ, 2004). If the long run expected prices of tea are higher than the total cost of a tea production, the tea farmer will continue to tea farming despite the price level below the short run average variable cost. If long run expected tea price is lower than total cost of production and current price level of tea is also lower than average variable cost, the tea farmer may prefer to shut down and exit from tea farming.

BOEHLJE, 1992 presented a life cycle assessment model to explain the relationship between farmer age and different farming decisions. He argued that the factors affecting the structural change decisions in agriculture have many dimensions. Structural changes in agriculture include entry, exit and enterprise composition. Moreover, BOEHLJE stated that five different types of factors (technology, human capital, financial condition, organizations, and sociology) influence agricultural structural changes. He also suggested that the farmers make important decisions about changes in agriculture structure differently at different stages of their lifecycles. For example, GALE (1994) reported that younger farmers have smaller farms and unlikely to have their own agricultural land as compared to older farmers. Older farmers reduced their enterprise size as they get older. He also suggested that certain investments are involved in moving from farm to non-farm jobs and the time to regain those investments is shorter for older farmers. His observation inferred that the sunk cost linked with investment rises with farmer tenure and was lower (higher) for younger (older) farmers. By using life cycle assessment model, he also suggested that a farm operator's judgment to exit from farming is similar to the firms' business cycle, where exit is more likely at the consolidation stage rather than at establishment or maturity.

Off farm income could be important source of stability during the fluctuation time and it may decrease costs, when moving from farm to a non-farm employment source (BRAGG \& DALTON, 2004). GOETZ and DEBERTIN (2001) reported that availability of off farm opportunities increases the farm exits; particularly in those countries which are suffering farm losses already.

It is not easy to define decision of exit and entry on the basis of long run costs of production because there are many implicit and explicit costs involved in performing farm operations and these costs are not easy to measure. In addition, there has been a strong custom in the locality which forces farmers not to sell their land inherited from their ancestors; instead giving it to shareholders who can operate the farm with their families is a preferred activity. Therefore, this study is designed to look at effect of factors affecting the long run decision to exit (giving farm to shareholders) or enter (landless farmers become shareholders) in tea farming through structural change model. We look at the impact of three types of variable on the exit and entry decision of farming; human capital (age, education, family size and presence of university graduate in family) organizations (membership of cooperatives) and off farm income (off farm occupation, Family Member having other occupation).

\section{MATERIALS AND METHODS}

\section{Study area and sample size}

The accessible population of tea growers was defined by using the method used by BOZ \& AKBAY (2005). The list of predetermined villages was obtained from a researcher from the agricultural 
department of the Rize province. The selection criteria of the villages for this study were their tea farming potential, location, and contribution toward the socio-economic condition of the residents. A list of tea farmers made manually was used to attain the potential sample size by using the formula proposed by YAMANE (2001). In total, 138 tea farmers were considered as the optimum sample size, and face-toface interviews were conducted.

$n=N \sum N_{h} S_{h}^{2} / N^{2} D^{2}+\sum N_{h} S_{h}^{2}, D^{2}=e^{2} / t^{2}$.

$\mathrm{n}=$ Sample size.

$\mathrm{N}=$ Population of tea growers in main strata.

$N_{h}=$ Number of tea growers in each stratum.

$S_{h}=$ Standard deviation within each stratum.

$D^{2}=$ Expected variance

$\mathrm{e}=$ Accepted error from mean .

$\mathrm{t}=$ Value of corresponding accepted confidence interval.

\section{Statistical analysis}

Firstly, a well-designed pre-tested questionnaire was developed and data collection was conducted by our research team in the study area. Both types of farmers, i.e., land-owners as well as farmers who gave their land to shareholders were accessed and interviewed. If the real owner of land could not be accessed, the required information was gathered from the shareholder. After completion of the survey, the data were analyzed by computer software, viz., Excel, SPSS, and SAS. Socioeconomic characteristics were compared by using the 'independent samples t-test' when variables were at the interval and normally distributed. Categorical variables were compared by the 'chi-square test' and when required by the 'Fisher's exact test'. Before applying the t-test', the variables were tested for their normality by the Kolmogorov Smirnov test. Logarithmic transformation was performed to normalize the variables.

\section{Logistic regression}

Logistic regression was applied twice in this study. Differences in the two models were the dependent variables. The first model describes the factors influencing the landholders to leave tea farming and influencing their decision to give their land to landless householders who wished to pursue tea farming. In this model, the dependent variable was expressed as ' 1 ' or ' 0 '; ' 1 ' was assigned to farmers who owned the land but decided to give it on share basis to a shareholder, and ' 0 ' to those who had both ownership and operation rights and were doing farming by themselves.
In the second model, the farmer who decided to work or to access land as a shareholder through the land tenure system was assigned ' 1 ', and ' 0 ' was assigned to a farmer who had both ownership and operational rights and also practiced tea farming. In this way, the Logistic model was developed, and the Probit model was derived from the latent model developed by SPERMANN, (2009).

$$
\begin{aligned}
& P\left(y_{i}=1 \mid \mathrm{x}\right)=\mathrm{P}\left(y_{i}^{*}>0 \mid x\right) \\
& =P\left(x_{i}^{\prime} \beta+\varepsilon_{i}>0 \mid x\right) \\
& =P\left(\varepsilon_{i}>-x_{i}^{\prime} \beta \mid x\right) \\
& =1-F\left(-x_{i}^{\prime} \beta\right)
\end{aligned}
$$

And

$P\left(y_{i}=1 \mid \mathrm{x}\right)=1-\Phi\left(-\frac{x_{i} \beta}{\sigma}\right), \sigma \equiv 1$

$\operatorname{Prob}(\mathrm{y}=1)$ is probability equal to 1 .

$\mathrm{x}$ is the vector of explanatory variables.

For estimation of odds ratios for explanatory variables, the following formula was used.

Exp (B) or odds $=P / 1-P$

Odds ratios demonstrate how much the probability of a farmer who is a shareholder or gives his land on a share basis will increase when a change of one unit in an independent variable occurs, while all other variables are held constant. The underlying latent model is described as:

$y_{i}^{*}=x_{i}^{\prime} \beta+\varepsilon_{i}$

$=\beta_{1} x_{1}+\beta_{2} x_{2}+\beta_{3} x_{3}+\beta_{4} x_{4}+\beta_{5} x_{5}+\beta_{6} x_{6}+\beta_{7} x_{7}+\beta_{8} x_{8}+\cdots+\beta_{n} x_{n}$

\section{Model 1}

$\mathrm{y}_{\mathrm{i}}^{*}$ Dependent variable $=1$ for a real owner of the land who gives it to a shareholder, otherwise 0 (who has both ownership and operation rights of land)

Age $\left(x_{1}\right)=$ Number of years.

Education $\left(x_{2}\right)=$ Schooling years.

Family Size $\left(x_{3}\right)=$ Number of family members.

Dummy for off-farm Occupation $(\mathrm{x} 4)=1$, if farmer has off-farm occupation; otherwise 0

Family Member having other occupation (x5) = Number of family members with other occupation

Membership of Cooperative (x6) $=1$ if farmer has any cooperative membership; otherwise 0 .

University Graduated family member $(x 7)=$ Number of university graduated family members

Membership of Cooperative (x8) $=1$ if farmer has any cooperative membership; otherwise 0

\section{Model 2}

Dependent variable $=1$ for shareholder who decided to access land on a share basis, otherwise 0 (who has own land and also doing tea farming). 
Age $\left(x_{1}\right)=$ Number of years.

Family Size $\left(x_{2}\right)=$ Number of family members.

Education $\left(x_{3}\right)=$ Schooling years.

University Graduated family member $\left(x_{4}\right)=$ Number of university graduated family members.

Family Member having other occupation $\left(x_{5}\right)=$ Number of family members with other occupation (No.). Membership of Cooperative $\left(x_{6}\right)=1$ if farmer has any cooperative membership; otherwise 0 .

Dummy for off-farm Occupation $\left(x_{7}\right)=1$, if farmer has off-farm occupation; otherwise 0 .

Dummy for Farmers' Wish $\left(x_{8}\right)=1$ if farmer has a wish of becoming successful farmer by his own effort; otherwise 0 .

\section{RESULTS AND DISCUSSION}

\section{The characteristics of the farmers}

Table 1 explains the personal characteristics associated with the sampled farmers. The farm owners were three years older than the shareholder farmers. Both groups had almost the same number of family members. More family members of farm-owner households were university graduated and also had other off-farm occupations as compared to those of the shareholder households. The tea farming experience of farm owners was higher than that of the shareholders. Although, no significant difference was observed between the family labor of both categories of farmers, more shareholders' family members were working at the farm. The farm owner households, on the average, were obtaining 42.48 percent of total family income from tea farming, whereas the total family income of shareholders was 50 percent from tea farming.

In general, a high percentage of farmers were primary school graduates. SAVAŞ \& YENICE (2016) also corroborated that a high number of farmers in the Rize province were primary school graduates. Compared to the farmers who had land tenure ship, the farm owners were educated up to the university level, whereas no one from shareholders families attended the university.

\section{Description of tea farms}

Table 2 describes the structure of tea farms. The land holding of the tea farm owners was just 7.68 decares with almost 5 parcels, whereas shareholders, on an average, held the land equal to 11.83 decares with 5.44 parcels. In concurrence to this study, YÜKSEK et al. (2013) also revealed that the majority of tea farmers were small farmers, and that very few farmers had more than 15 decares, constituting 4-7 parcels. Tea land to parcel ratio demonstrated that the farm owners created more parcels than those by shareholders. The parcels were almost 39 years old and remained almost 11 years from the economic age of tea plants as reported by ÖZCAN \& YAZICIOĞLU, (2013). It was also observed that the slope and altitude of tea orchards of shareholders were higher than those of farm owners. Additionally, the yield of tea and labor productivity as measured by the collection of tea leaves per day was higher at shareholders farms. Similarly, PENDER \& FAFCHAMPS (2005) did not find a significant

Table 1 - Farmers' characteristics.

\begin{tabular}{|c|c|c|c|c|c|}
\hline \multirow[t]{2}{*}{ Characteristics } & \multicolumn{2}{|c|}{-------------------Owner--------------- } & \multicolumn{2}{|c|}{------------Shareholder----------- } & \multirow[t]{2}{*}{ P- Value } \\
\hline & Mean & Std. Deviation & Mean & Std. Deviation & \\
\hline Age (Years) & 50.37 & 12.52 & 47.37 & 9.83 & 0.25 \\
\hline Household size (No.) & 4.64 & 1.85 & 4.63 & 1.62 & 0.94 \\
\hline Experience (Years) & 32.60 & 13.10 & 29.96 & 10.58 & 0.33 \\
\hline University graduated family members (No.) & 1.14 & 1.10 & 0.66 & 0.83 & 0.04 \\
\hline Family members having other occupation (No.) & 1.35 & 1.33 & 0.93 & 1.11 & 0.13 \\
\hline Family labor at farm (No.) & 2.00 & 0.95 & 2.30 & 0.87 & 0.42 \\
\hline Family income (TL/Year) & 32144.14 & 21145.45 & 30977.78 & 36244.02 & 0.83 \\
\hline Farm income share in family income (\%) & 42.48 & 24.40 & 50.04 & 26.39 & 0.16 \\
\hline Education of farmers & \multicolumn{2}{|c|}{ Percent } & \multicolumn{2}{|c|}{ Percent } & \\
\hline Primary school & \multicolumn{2}{|c|}{38.74} & \multicolumn{2}{|c|}{59.26} & \\
\hline Secondary school & \multicolumn{2}{|c|}{19.82} & \multicolumn{2}{|c|}{14.81} & \\
\hline High school & \multicolumn{2}{|c|}{19.82} & \multicolumn{2}{|c|}{18.52} & 0.302 \\
\hline University graduated & \multicolumn{2}{|c|}{19.82} & \multicolumn{2}{|c|}{7.41} & \\
\hline Master/Doctorate & \multicolumn{2}{|c|}{1.80} & \multicolumn{2}{|c|}{0.00} & \\
\hline
\end{tabular}

Ciência Rural, v.50, n.12, 2020. 
Table 2 - Farm structure and tea yield.

\begin{tabular}{|c|c|c|c|c|c|}
\hline & \multicolumn{2}{|c|}{------------------Owner--------------- } & \multicolumn{2}{|c|}{------------Shareholder---------- } & \multirow[t]{2}{*}{ P-Value } \\
\hline & Mean & Std. Deviation & Mean & Std. Deviation & \\
\hline Land under tea & 7.68 & 6.29 & 11.83 & 8.85 & 0.01 \\
\hline No. of parcels & 4.99 & 3.56 & 5.44 & 2.15 & 0.53 \\
\hline Age of parcels & 38.20 & 13.92 & 39.57 & 14.19 & 0.65 \\
\hline Slop (\%) & 39.97 & 16.83 & 42.30 & 16.10 & 0.52 \\
\hline Altitude (m) & 316.32 & 265.61 & 392.11 & 370.00 & 0.22 \\
\hline Distance from reception point $(\mathrm{m})$ & 1081.53 & 882.40 & 1224.26 & 1025.19 & 0.47 \\
\hline Labor productivity (Kg/Man/Day) & 250.11 & 64.60 & 281.48 & 60.09 & 0.02 \\
\hline Yield $(\mathrm{Kg} / \mathrm{De})$ & 1482.03 & 454.00 & 1457.10 & 395.87 & 0.93 \\
\hline
\end{tabular}

difference between the yields of shareholders and owner operated plots.

\section{Tea management practices}

Table 3 represents the terrace status at tea farms in the study area. Terracing (making graduated terrace steps) was being practiced in the study area to minimize the risk of erosion or landslide and make orchards easy to manage. But terracing is not fully adopted by both categories of farmers, although it is a necessity for tea farming. A high percentage of shareholders (40.74 percent) were

Table 3 - Management practices.

\begin{tabular}{|c|c|c|c|}
\hline & Owner & Shareholder & P-value \\
\hline \multicolumn{4}{|c|}{-------------------------------------------------------------------------------Terrace status----------------------------------------------------------------- } \\
\hline Yes & 68.47 & 44.44 & \multirow{3}{*}{0.06} \\
\hline No & 24.32 & 40.74 & \\
\hline No need & 7.21 & 14.81 & \\
\hline \multirow{3}{*}{\multicolumn{4}{|c|}{ 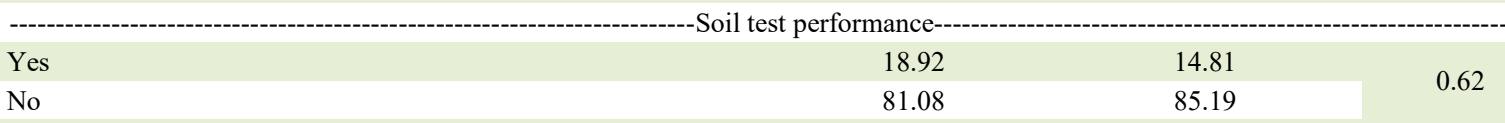 }} \\
\hline & & & \\
\hline & & & \\
\hline \multirow{3}{*}{\multicolumn{4}{|c|}{ 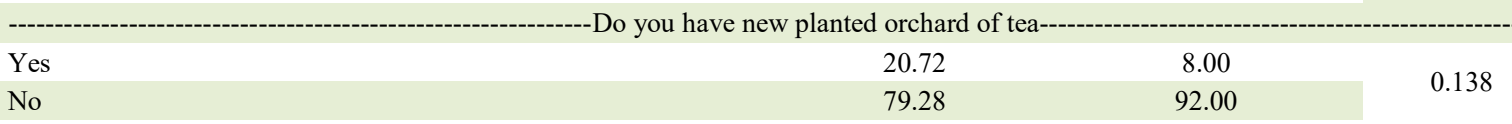 }} \\
\hline & & & \\
\hline & & & \\
\hline \multicolumn{4}{|c|}{ 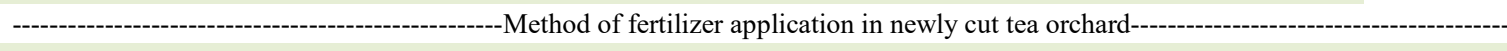 } \\
\hline Spreading & 60.58 & 57.69 & \multirow{3}{*}{0.712} \\
\hline In root zone & 35.58 & 42.31 & \\
\hline Mix with soil & 3.85 & 0.00 & \\
\hline \multicolumn{4}{|c|}{ 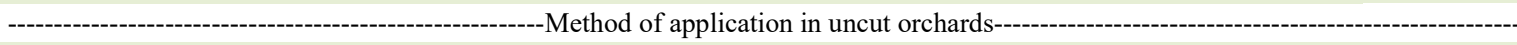 } \\
\hline Spreading & 61.11 & 76.00 & \multirow{2}{*}{0.162} \\
\hline In root zone & 38.89 & 24.00 & \\
\hline \multicolumn{4}{|c|}{ - } \\
\hline Pulling off with hand before harvesting tea & 79.28 & 74.07 & \multirow{3}{*}{0.635} \\
\hline Pulling off during tea harvesting & 1.80 & 0.00 & \\
\hline Others (Motor) & 18.92 & 25.93 & \\
\hline \multicolumn{4}{|c|}{ 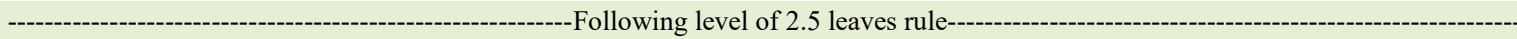 } \\
\hline Yes & 19.82 & 22.22 & \multirow{3}{*}{0.935} \\
\hline Occasionally & 40.54 & 37.04 & \\
\hline No & 39.64 & 40.74 & \\
\hline
\end{tabular}

Ciência Rural, v.50, n.12, 2020. 
not practicing terracing at their orchards. Almost 7 percent owners and 14 percent shareholders reported that they did not need terracing at their tea land. The aspect of emotional ties to land as owners or as tenants significantly affects the decision of farmers to protect the soil of the tea orchards.

The practice of performing soil test in this study was poor. Only 18.92 percent owners and 14.81 percent shareholder farmers were performing the soil test. Although, soil testing is a good practice for maintaining soil health, the farmers are utilizing chemical fertilizers in tea farming without performing a soil test. This not only affects soil health but may also affect the tea quality. Such fertilizers, applied in high quantities, can lead to soil deterioration and eventually to high production costs. ÖZCAN \& YAZICIOĞLU (2013) also observed that the farmers fertilize their orchards without a soil test performance. Unlike the shareholders, the farm owners were keen to plant new tea orchards. The spreading method was the commonly practiced method for applying fertilizers to both newly cut and uncut tea orchards. In addition, only 3.85 percent farm owners preferred to apply fertilizers by mixing them in the soil in newly cut tea plots. In uncut tea orchards, the application of fertilizer was difficult and farmers preferred the spreading method for fertilizer application. YÜKSEK et al. (2013) reported that in the newly cut tea orchards, farmers applied fertilizers in the root zone, whereas in uncut orchards, the spreading method was widely adopted.

The farmers were getting rid of herbs (weeds) growing in the tea farms without using chemical herbicides. They pull off herbs during harvesting or before harvesting the tea. Mostly, the farmers pull off herbs manually before the harvesting season and only 1.80 percent owned tea farmers use the method during tea harvesting. Furthermore, 18.92 percent owners and 25.93 percent shareholders use motors for the removal of herbs from tea orchards.
Farmers were following the ' 2.5 Leaves Rule' (the rule describes the quantity of $2.5 \mathrm{~cm}$ tall tea leaves as compared to shorter or taller in the total harvested quantity of tea). A higher percentage of owners (40.54 percent) were occasionally following this rule; only 19.82 percent of them were following it on every occasion of harvesting. Only 22.22 percent of shareholders followed this rule diligently, whereas 37.04 percent were occasional followers. Moreover, 39.64 percent owners and 40.74 percent shareholders did not follow this rule at all.

\section{Profitability of tea farming}

As shown in table 4, the shareholders were spending 619.87 Turkish Lira (TL) per decare (TL/ De) and were earning a gross income of 3148.28 TL/De. Conversely, the returns of farm owners were $2857.08 \mathrm{TL} / \mathrm{De}$ after spending on inputs equal to $565.94 \mathrm{TL} / \mathrm{De}$, thus demonstrating that the gross margin and management returns of shareholders were greater than those of farm owners. Haq and Boz (2019) also described that shareholders manage their farms more efficiently which ultimately results in high income.

\section{Assessing the factors influencing the real owner's decision to give their land to shareholders}

Table 5 depicts the relationship between predictors and decisions of the farmers to give land to shareholders and leave tea farming due to various reasons. Mostly these farmers do not stay in the study area. The probability of giving land to shareholder increases as the age and education of real owner increases; both the variables have a significant effect on the likelihood of the real owner to give land to the shareholder. The family size has an insignificant, negative relation with the probability of giving their land to shareholders. Wang et al. (2015) summarized contrasting results, wherein they reported that the large households are more likely to rent out their land to non-relatives. The farmers having off-farm

Table 4 - Tea farming profitability (TL/De).

\begin{tabular}{|c|c|c|c|c|c|}
\hline & \multicolumn{2}{|c|}{ 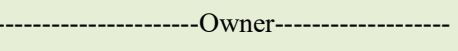 } & \multicolumn{2}{|c|}{-----------------Shareholder---------------- } & \multirow[t]{2}{*}{ P-value } \\
\hline & Mean & Std. Deviation & Mean & Std. Deviation & \\
\hline Variable cost & 565.94 & 482.35 & 619.87 & 520.68 & 0.61 \\
\hline Return & 2857.08 & 958.06 & 3148.28 & 879.82 & 0.15 \\
\hline Gross margin & 2291.14 & 991.59 & 2528.41 & 1039.51 & 0.27 \\
\hline Return to management & 1499.08 & 1061.27 & 1851.07 & 981.72 & 0.12 \\
\hline
\end{tabular}

Ciência Rural, v.50, n.12, 2020. 
Table 5 - Factors influencing the probability of giving land to shareholder.

\begin{tabular}{|c|c|c|c|c|c|}
\hline Parameters & Estimate $(\beta s)$ & Std. Error & t-value & p-value & Odds Ratios \\
\hline Intercept & -4.765 & 1.247 & -3.820 & 0.000 & 0.0002 \\
\hline Age (Years) & 0.036 & 0.014 & 2.600 & $0.009^{* *}$ & 1.07 \\
\hline Education (Schooling Years) & 0.134 & 0.043 & 3.110 & $0.002^{*}$ & 1.27 \\
\hline Family size (No.) & -0.054 & 0.119 & -0.450 & 0.651 & 0.90 \\
\hline Dummy for off-farm Occupation & 1.296 & 0.391 & 3.320 & $0.001^{*}$ & 10.01 \\
\hline family member having other Occupation (no.) & 0.010 & 0.136 & 0.070 & 0.943 & 1.05 \\
\hline University graduated family member (no.) & 0.156 & 0.158 & 0.990 & 0.322 & 1.27 \\
\hline Membership of cooperative & -0.729 & 0.355 & -2.050 & $0.040^{*}$ & 0.28 \\
\hline
\end{tabular}

Independent variable $(\mathrm{Y})=1$ for real owner of land (not doing farming) and 0 for owned farmers; Log Likelihood = 41.193 ; AIC Value $=98.386 ;$ SC Value $=121.804 ;$ Likelihood Ratio $=54.045 ; \chi^{2}=54.05$ Pseudo $\mathrm{R}^{2}=0.396$; Correctly Classified $=85.51 \%$.

occupations are more likely to give up tea farming as compared to those who do not have such occupations by a factor of 10.01. A higher number of members having other occupations and the number of university graduate members in farmers' family resulted in an increased likelihood of them giving land to shareholders and also enhance chances to give up tea farming. Farmers having a cooperative membership are less likely to give their land on a share basis and prefer to work on land by themselves. In China, where the land sale is impossible, the development of off-farm sector has eliminated obstructions in the functioning of the rental market, thus improving productivity (BENJAMIN \& BRANDT, 2004). The farmers who actively participate in the off-farm activities or occupations are highly probable to supply land in rental market (ZHANG et al., 2004). YAO (2000) and LOHMAR et al. (2001) also described that as the number of villages moving toward off-farm occupations increases; the amount of land potentially available for rent also increases.

\section{Assessing the factors influencing landless households to act as shareholders}

Table 6 explains an additional independent variable, such as the desire of a farmer to become successful by his own effort. The model assesses the variables which influence a landless farmer's decision to acquire land and work as a shareholder. As a farmer's age increases, the probability of the farmer to work as a shareholder decreases. FENG \& HEERINK (2008) suggested that as a household head gets older and his education level increases, the probability of renting land declines. Similarly, highly educated farmers are less likely to access land and are less likely to work as shareholders. These results are in line with

Table 6 - Factors influencing the likelihood of a landless household to act as a shareholder.

\begin{tabular}{|c|c|c|c|c|c|}
\hline Parameters & Estimate $(\beta \mathrm{s})$ & Std. Error & t-value & p-value & Odds Ratios \\
\hline Intercept & 1.61 & 0.91 & 1.77 & 0.08 & 19.587 \\
\hline Age (Years) & -0.02 & 0.01 & -1.88 & $0.06^{* *}$ & 0.96 \\
\hline Family size (No.) & -0.01 & 0.08 & -0.10 & 0.92 & 1.00 \\
\hline Education (Schooling Years) & -0.08 & 0.04 & -1.90 & $0.06^{* *}$ & 0.87 \\
\hline University graduated family member (No.) & -0.15 & 0.15 & -1.00 & 0.32 & 0.76 \\
\hline Family member having other occupation (No.) & -0.08 & 0.11 & -0.67 & 0.51 & 0.88 \\
\hline Membership of cooperative & -0.18 & 0.27 & -0.64 & 0.52 & 0.73 \\
\hline Dummy for off-farm occupation & -0.01 & 0.27 & -0.05 & 0.96 & 0.99 \\
\hline Dummy for farmers' wish & -0.48 & 0.29 & -1.67 & $0.09^{* *}$ & 0.44 \\
\hline
\end{tabular}

Independent variable $(\mathrm{Y})=1$ for shareholder and 0 for owned farmer; Log Likelihood $=-60.75$; AIC Value $=139.50$; SC Value $=$ 165.84; Likelihood Ratio $=14.93$; Pseudo $\mathrm{R}^{2}=0.11$; Correctly Classified $=81.16 \%$. 
the findings of KUNG (2002), who described similar results. It is observed that the family size and the probability of working as a shareholder are inversely related. FENG, (2008) has demonstrated a positive correlation between the probability of renting land with the family size and negative correlation with the age of the household's head. He also suggested that there is a negative correlation between the probabilities of renting land with the education level of a household. These results implied that a large family size exerts a pressure on a household toward getting short-term incomes. The landless people try to work in other off-farm occupations to get income on daily or monthly basis because tea farming gives income after a long period (long-term gains). Further, having a high number of university graduates in a family and members working at off-farm occupations decreases the probability of landless households to access land and to act as shareholders. These results agreed with the studies of ZHANG et al. (2004), who reported similar findings. The farmers who are the members of cooperatives and those who desire to be successful at farming with their own efforts are less likely to work as shareholders and prefer to have selfowned land. DEININGER \& JIN (2008) also revealed that younger household heads are more likely to rent land. As they get older, more educated, and have more off-farm occupations; the probability to rent the land reduces. A similar observation associated with the off-farm occupation and land renting was made by KUNG (2002).

\section{CONCLUSION}

The development of land tenure markets in agriculture plays an important role in enhancing productivity, improving income and overall welfare of the rural households. It is the cheapest way of acquiring land, which allows even landowners to enjoy land ownership rights without selling off their land. We observed that farmers who were shareholders were younger and their education level was also low as compared to farm owners. Although, an owner's family income was higher than that of a shareholder, the share of agricultural income in a shareholder's total family income was higher than land owner. The family size was almost the same for both types of farmers.

On an average, the total tea land of shareholders farms was greater than that of their counterparts. The labor productivity was also high at the shareholder farms. In this study, it was observed that shareholders did not follow the practice of terracing at their farms even though it was a necessity for increasing the productivity of tea. Soil test performance was not common in the study area, though more farm owners were performing soil test than the shareholders. Results also demonstrated that fertilizers were generally applied through spreading method in tea orchards and that some of the farm owners were also applying fertilizers by mixing them in the soil in newly cut tea orchards. In uncut orchards, the farmers mostly used the spreading method, but a high percentage of owners also applied fertilizers to the root zone. We also noted that farm owners occasionally followed the 2.5 leaves rule, whereas a high percentage of shareholders did not follow this rule. Both categories of farmers enjoyed good returns from tea farming. Moreover, the shareholders returned to tea farm management because of good turnover at these farms.

The overall model was highly significant and 85.51 percent correctly specified. On the supply side, the factors affecting the decision of farmers to provide land to the land tenure market were the age of the respondent, education, off-farm occupation and cooperative membership. An increase in the family size along with the membership of cooperative societies made farmers less likely to provide their land to the land market. Such farmers gave land to other farmers on a share basis. Older and highly educated farmers were more likely to leave farming and to make their land available to the land market. In this study, we have also shown that the number of university graduates and the number of members having other occupations in a family did not have a significant impact on the likelihood of farmers giving land to shareholders.

The age of the farmers, the schooling years completed and the wish to become successful farmers did not have a significant influence on the decision of farmers to access land as shareholders. As farmers became older they did not access land in the land market. Larger the family size, the greater was the chance of a farmer to act as an owner rather than a shareholder. Having more university graduates and members having an off-farm occupation in a family reduced the probability of accessing land. Moreover, it was seen that farmers having other occupations were less likely to work as shareholders. Lastly, we have also observed that the aspiration of farmers to become successful by using their own efforts increased the probability of the farmer to work as an owner and not as a shareholder.

In conclusion, the theoretical background and empirical results of this study showed that the decision to exit farming by tea producing land owners 
(giving farm to shareholders), and to enter farming as a shareholder (landless families start farming in a shareholder basis) depends not only on production costs and farm income but also on human capital variables, membership of farmers' organizations, and off farm income opportunities in the locality. The more these factors would be functional the more landowners will abandon farming and start to engage in off farm occupation. Technical, economic, and social impacts of this new farming system would be a new subject for researchers to investigate.

\section{ACKNOWLEDGEMENTS}

No funding was obtained to carry out this study from any individual or organization.

\section{BIOETHICS AND BIOSSECURITY COMMITTEE APPROVAL DECLARATION}

We authors of the article entitled "An examination of land tenure in tea farming and exploring the factors influencing the rural household's decision to exit and entry in farming" declared, for all due purposes, the project that gave rise to the present data of the same has not been submitted for evaluation to the Ethics Committee of the University /Research Institute "Ondokuz Mayis University, Samsun Turkey", but we are aware of the contents of Resolution No. 466, of December 12, 2012 of the Brazilian National Health Council "http://conselho.saude.gov.br/ resolucoes/2012/Reso466.pdf" if it involves human. Thus, the authors assume full responsibility for the presented data and are available for possible questions, should they be required by the competent authorities.

\section{DECLARATION OF CONFLICT OF} INTERESTS

The authors declare no conflict of interest. The founding sponsors had no role in the design of the study; in the collection, analyses, or interpretation of data; in the writing of the manuscript, and in the decision to publish the results.

\section{AUTHORS' CONTRIBUTIONS}

The authors contributed equally to the manuscript.

\section{REFERENCES}

AFT,(2013). TheAdoption of Conservation Practices in Agriculture American Farmland Trust Center for Agriculture in the Environment DeKalb, Illinois. Available from: $<$ http://162.242.222.244/documents/ AdoptionofConservationPracticesinAg_FINAL.pdf $>$. Accessed: Oct. $18,2019$.

BASHIR, A., et al. (2012). Impact of sugarcane mills development activities on cane production in Punjab. Pakistan Journal of Agricultural Research, 25(1), 21-27. Available from: < https:// www.researchgate.net/publication/283583275_Impact_of
Sugarcane_Mills_Development_Activities_on_Cane_Production_ in_Punjab>. Accessed: Oct. 18, 2019.

BENJAMIN, D.; BRANDT, L. (2004). Agriculture and income distribution in rural Vietnam under economic reforms: a tale of two regions. Economic growth, poverty, and household welfare in Vietnam, 133-186. Available from: <https://core.ac.uk/download/ pdf/9307152.pdf $>$. Accessed: Oct. 18, 2019.

BOEHLJE, M. (1992). Alternative models of structural change in agriculture and related industries. Agribusiness, 8(3), 219-231. Available from: <https:// doi.org/10.1002/1520-6297(199205)8:3\%3C219::AIDAGR2720080303\%3E3.0.CO;2-T>. Accessed: Oct. 18, 2019.

BOZ, I.; AKBAY, C. (2005). Factors influencing the adoption of maize in Kahramanmaras province of Turkey. Agricultural Economics, 33(s3), 431-440. Available from: <https://doi.org/ 10.1111/j.1574-0864.2005.00305.x>. Accessed: Oct. 18, 2019.

BRASSELlE, A. S., GASPART, F., \& PLATTEAU, J. P. (2002). Land tenure security and investment incentives: puzzling evidence from Burkina Faso. Journal of Development Economics, 67(2), 373-418. Available from: <https://doi.org/10.1016/S03043878(01)00190-0>. Accessed: Oct. 18, 2019.

BUGRI, J. T. (2008). The dynamics of tenure security, agricultural production and environmental degradation in Africa: Evidence from stakeholders in north-east Ghana. Land Use Policy, 25(2), 271-285. Available from: <https://doi.org/10.1016/j. landusepol.2007.08.002>. Accessed: Oct. 18, 2019.

COX, E. (2010). The Landowner's Guide to Sustainable Farm Leasing. Drake University Agricultural Law Center. Available from: <https://lib.dr.iastate.edu/cgi/viewcontent.cgi?article=1099 \&context=leopold_pubspapers $>$. Accessed: Dec. 12, 2019.

DE JANVRY, A., et al. (2001). Access to land, rural poverty, and public action. Oxford University Press., Available from: $<$ https:// econpapers.repec.org/bookchap/oxpobooks/9780199242177. htm>. Accessed: Jan. 10, 2020.

DEININGER, K., \& FEDER, G. (2001). Land institutions and land markets. Handbook of agricultural economics, 1, 287-331. Available from: <https://doi.org/10.1016/S1574-0072(01)100095>. Accessed: Jan. 10. 2020.

DEININGER, K. Land markets in developing and transition economies: Impact of liberalization and implications for future reform. American Journal of Agricultural Economics, v.85, n.5, p.1217-1222, 2003. Available from: < https://doi.org/10.1111 /j.0092-5853.2003.00533.x> Accessed: Sep. 28,2017.

DEININGER, K., \& JIN, S. (2005). The potential of land rental markets in the process of economic development: Evidence from China. Journal of Development Economics, 78(1), 241-270. Available from: <https:// doi.org/10.1016/j.jdeveco.2004.08.002>. Accessed: Jan. 10, 2020.

DEININGER, K., \& JIN, S. (2008). Land sales and rental markets in transition: Evidence from rural Vietnam. Oxford Bulletin of Economics and Statistics, 70(1), 67-101. Available from: $<$ https://doi.org/10.1111/j.1468-0084.2007.00484.x>. Accessed: Jan. 10, 2020

FAO, 2017. Land Tenure and Rural Development. Economic and Social Development Department, Food and Agricultural 
Organization. Available from: <http://www.fao.org/3/a-y4307e. pdf>. Accessed: Oct. 12, 2019.

FENG, S. (2008). Land rental, off-farm employment and technical efficiency of farm households in Jiangxi Province, China. NJASWageningen Journal of Life Sciences, 55(4), 363-378. Available from: <https://doi.org/10.1016/S1573-5214(08)80026-7>. Accessed: Oct. 12, 2019.

FENG, S., \& HEERINK, N. (2008). Are farm households' land renting and migration decisions inter-related in rural China? NJAS-Wageningen Journal of Life Sciences, 55(4), 345-362. Available from: < https://doi.org/10.1016/S1573-5214(08)800255>. Accessed: Oct. 12, 2019

FOLTZ, J. D. (2004). Entry, exit, and farm size: assessing an experiment in dairy price policy. American Journal of Agricultural Economics, 86(3), 594-604. Available from: $<$ https://doi.org/10.1111/j.0002-9092.2004.00603.x>. Accessed: Oct. 12, 2019.

FRASER, E. D. (2004). Land tenure and agricultural management: soil conservation on rented and owned fields in southwest British Columbia. Agriculture and Human Values, 21(1), 73-79. Available from: < https://doi.org/10.1023/B:AHUM.0000014020.96820.a1>. Accessed: Oct. 12, 2019.

GALE, H. F., Jr. 1994. Longitudinal analysis of farm size over the farmer's life cycle. Rev. Agric. Econ. 16:113-123. Available from: $<$ https://doi.org/10.2307/1349526>. Accessed: Oct. 12, 2019.

GEBREMEDHIN, B., \& SWINTON, S. M. (2003). Investmen in soil conservation in northern Ethiopia: the role of land tenure security and public programs. Agricultural economics, 29(1), 69 84. Available from: <https://doi.org/10.1111/j.1574-0862.2003. tb00148.x>. Accessed: Oct. 12, 2019.

GOETZ, S. J., DEBERTIN, D. 2001. Why farmers quit: A countylevel analysis. Am. J. Agric. Econ. 83:1010-1023. Available from: $<$ https://doi.org/10.1111/0002-9092.00226>. Accessed: Dec. 20, 2019.

HAQ, S., BOZ, I. (2019). Estimating the efficiency level of different tea growing systems in the province of Rize in Turkey. Cienc. Rural, [online]. 2019, vol.49, n.12, e20181052. Epub Nov 25, 2019. ISSN 1678-4596. Available from: <https://doi. org/10.1590/0103-8478cr20181052>. Accessed: Dec. 20, 2019.

JOHNSON, G.L., et al. 1961. A Study of Managerial Processes of Midwestern Farmers. Iowa State Press, Ames, Iowa Available from: <https://agris.fao.org/agris-search/search do? recordID $=$ US201300540798 $>$. Accessed: Oct. 20, 2019

KATZ, E. G. (2000). Social capital and natural capital: a comparative analysis of land tenure and natural resource management in Guatemala. Land economics, 114-132. Available from: $\quad<$ https://www.jstor.org/stable/3147261?seq=1\#metadata info_tab_contents $>$. Accessed: Dec. 20, 2019.

KUNG, J. K. S. (2002). Off-farm labor markets and the emergence of land rental markets in rural China. Journal of Comparative Economics, 30(2), 395-414. Available from: <https://doi. org/10.1006/jcec.2002.1780>. Accessed: Dec. 20, 2019.

LOHMAR, B., ZHANG, Z., SOMWARU, A. (2001). Land rental market development and agricultural production in China. In:
Annual Meeting of the American Agricultural Economics Association, (Vol. 5, No. 8).

MAXWELL, D., WIEBE, K. (1999). Land tenure and food security: Exploring dynamic linkages. Development and Change, 30(4), 825-849. Available from: < https://doi.org/10.1111/14677660.00139>. Accessed: Dec. 20, 2019.

ÖZCAN, M., YAZICIOĞLU, E. (2013). Türkiye çay yetiştiriciliğinin sorunları ve öncelikleri. II. Rize Kalkınma Sempozyumu Cay - Lojistik - Turizm Rize, 3 - 4 Mayıs 2013 Bildiriler Kitab1. Available from: <https://silo.tips/download/iirze-kalkinma-sempozyumu-7>. Accessed: Sep. 03, 2019.

PENDER, J., FAFCHAMPS, M. Land lease markets and agricultural efficiency in Ethiopia. Journal of African Economies, 15(2), 251-284. Available from: < https://doi.org/10.1093/jae/ eji024>. Accessed: Sep. 03, 2019.

PRANEETVATAKUL, S., et al. (2001). Assessing the sustainability of agriculture: a case of Mae Chaem Catchment, northern Thailand. Environment International, 27(2), 103-109. Available from: $<$ https://doi.org/10.1016/S0160-4120(01)00068-X>. Accessed: Sep. 03, 2019.

SAVAȘ, S., YENICE, G. (2016). Rize ilinde yapılan süt sığırcılığının mevcut durumunun araştırılması. Atatürk Üniversitesi Veteriner Bilimleri Dergisi, 11(1). Available from: $<$ https://doi.org/10.17094/avbd.60910>. Accessed: Sep. 03, 2019.

SIMON, H.A., 1965. The Shape of Automation. Harper and Row, New York.

SOULE, M. J., TEGENE, A., WIEBE, K. D. (2000). Land tenure and the adoption of conservation practices. American journal of agricultural economics, 82(4), 993-1005. Available from: <https://doi.org/10.1111/0002-9092.00097>. Accessed: Sep. 03, 2019.

SPERMANN, A. (2009). The probit model. University of Freiburg, 2009.

TEKLU, T., LEMI, A. (2004). Factors affecting entry and intensity in informal rental land markets in Southern Ethiopian highlands. Agricultural Economics, 30(2), 117-128. Available from: $<$ https://doi.org/10.1111/j.1574-0862.2004.tb00181.x>. Accessed: Sep. 03, 2019.

TUIK, (2017). Turk Statistical Institute, 2.4. Number of agricultural holdings and the land operated by size of agricultural holdings and land tenure forms. Available from: $<$ http://www.tuik.gov.tr/UstMenu.do?metod=temelist $>$. Accessed: Oct. 18, 2018.

TURNER, J. R., BAKER, R., KELLNER, F. (2018). Theoretical literature review: Tracing the life cycle of a theory and its verified and falsified statements. Human Resource Development Review, 17(1), 34-61. Available from: < https://doi.org/10.1177\% 2F1534484317749680>. Accessed: Sep. 03, 2019.

UL-HAQ, S., BOZ, İ., SHAHBAZ, P. (2016). Problems encountered by dairy farms and their possible solutions in Punjab region of Pakistan. Ziraat Fakültesi Dergisi, Uludağ Üniversitesi, 30(Special Issue), 176-183. Available from: < https://www.cabdirect.org/cabdirect/abstract/20173246060>. Accessed: Sep. 03, 2019. 
USAID, 2013. Land Tenure. Natural Resource Management and Development Portal. Linking nature, wealth and Power for Resilience Development. Available from: <https://rmportal. net/library/content/tools/land-tenure-and-property-rights tools/ index_html/copy_of_definition-land-tenure $>$. Accessed: Sep. 28,2017 .

WANG, H., RIEDINGER, J., JIN, S. (2015). Land documents, tenure security and land rental development: Panel evidence from China. China Economic Review, 36, 220-235. Available from: $<$ https://doi.org/10.1016/j.chieco.2015.09.005 $>$. Accessed: Sep. 28, 2018.

YAMANE, T. 2001. Temel Örnekleme Yöntemleri. Çevirenler: Alptekin Esin, Celal Aydın, M. Akif Bakır, Esen Gürbüzsel. Literatür Yayıncılık, İstanbul.
YAO, Y. (2000). The development of the land lease market in rural China. Land Economics, 252-266. Available from: $<$ https://www. jstor.org/stable/3147227?seq=1\#metadata_info_tab_contents $>$. Accessed: Oct. 10, 2019.

YÜKSEK, T., YÜKSEK, F., SÜTLÜ, E., (2013). Rize Yöresinde Çay Tariminda Gübreleme Sorunlari Ve Sürdürülebilir Çay Tarimi İçin Yeni Stratejiler. Bildiriler Kitabı, 89. Available from: <http:// www.soneresmer.com/downloads/puplications/sempozyumkitap. pdf\#page $=87>$. Accessed: Oct. 10, 2019 .

ZHANG, Q. F., et al. (2004). Development of land rental markets in rural Zhejiang: Growth of off-farm jobs and institution building. The China Quarterly, 180, 1031-1049. Available from: <https://www. jstor.org/stable/20192417?seq=1\#metadata_info_tab_contents $>$. Accessed: Oct. 16, 2019. 